Citation:

Yu, X. and Lo, A. Y. (2015) Carbon Finance and the Carbon Market in China. Nature Climate Change, 5, pp.15-16

Publisher version available from the authors: alexloyh@hku.hk

\title{
COMMENTARY:
}

\section{Carbon finance and the carbon market in China}

\section{Xiang Yu and Alex Y. Lo}

Chinese carbon market is up and running, but private finance has not been fully utilized. Finance-friendly policies are needed to help the world's largest greenhouse gas emitter to harness market forces for climate change mitigation.

The latest World Bank report on carbon pricing indicates that the world's emission trading schemes (ETS) are currently worth about US\$30 billion (ref. 1). ETSs create a market in which the rights to emit greenhouse gases (GHG) are traded among GHG-emitting entities. The trading of emissions allowances or credits in these carbon markets creates a price on carbon and can help mitigate GHG emissions at lower costs. The world's largest carbon market is built upon the European Union (EU) ETS, with an emission cap of 2,084 MtCO2e in 2013. China houses the second largest one, covering 1,115 MtCO2e (ref. 1).

China pledges to reduce its carbon dioxide emissions per unit of GDP by $40-45 \%$ by 2020, compared with 2005 levels. The world's largest national source of GHG emissions has recently embarked on one of the largest endeavours in tackling climate change. In 2011, China announced a plan to introduce mandatory ETSs to support GHG mitigation. Seven cities and provinces were appointed across the country to implement pilot emission trading. These pilot sites are located in various parts of China with different economic structures and development trajectories, including Beijing, Tianjin, Shanghai, Chongqing, Shenzhen, Guangdong and Hubei. By June 2014, all seven pilot ETSs have started trading, at varying trading prices and levels of activity (Table 1). The first pilot phase is expected to complete in end of 2015 or 2016; it is intended to build experience and provide lessons for moving toward a national cap-and-trade system in the following years. 
Table 1 Traded volumes and average prices in the pilot ETSs (as of 22 August 2014)

\begin{tabular}{lrrrrrrr} 
& \multicolumn{1}{c}{ Beijing } & \multicolumn{1}{c}{ Shanghai } & Guangdong & Shenzhen & Tianjin & Hubei & Chongqing \\
\hline Launch date & 28 November & 26 November & 18 December & 18 June & 26 December & 2 April & 19 June \\
$\begin{array}{l}\text { Traded volume } \\
\text { (tCO2e) }\end{array}$ & 2013 & 2013 & 2013 & 2013 & 2013 & 2014 & 2014 \\
$\begin{array}{l}\text { Average price } \\
\text { (\$US/tCO2e) }\end{array}$ & $2,031,876$ & $1,553,460$ & $1,293,173$ & $1,647,790$ & $1,059,760$ & $5,185,695$ & 145,000 \\
& 8.0 & 6.4 & 8.9 & 11.1 & 3.4 & 3.9 & 5.0 \\
\hline
\end{tabular}

Source: Shanghai Environment and Carbon Exchange ‘Carbon Market Express' Vol. 37, August 2014 (http://www.cneeex.com)

With government strong support, these ETSs were approved and came into force within a short period of time, i.e. about 3.5 years $(2011$ - 2014) from preparation to official launch (ref. 2). The market mechanism, however, is associated with a number of problems, such as poor GHG measuring and reporting practice, incomplete legal frameworks, non-compliance, ineffective enforcement and low penalties (ref. 3, 4). Apart from these technical and regulatory failures, the market itself remains illiquid, i.e. there are few participants and the volume of transactions is low. Failure to increase liquidity may affect the efficiency outcomes of emission trading, which is, in China, subject to a suite of institutional constraints not experienced by their European and American counterparts.

In remainder of this commentary we discuss the financial potential for emission trading in China. The discussion is informed by a comprehensive review of literature and five in-depth interviews with representatives from the Chinese financial industry completed in mid-July 2014. These industry representatives are senior executives who have extensive experience and knowledge in China's carbon finance, and have been actively involved in the Chinese CDM market and the pilot ETSs in various ways. They are members of management teams or department chiefs in leading Chinese entreprises enterprises that have already established carbon finance operations, including the general manager of a carbon asset management firm (a subsidiary of a 'top five' national power company), the strategic director of a consultancy firm specializing in low-carbon investment (a subsidiary of a leading private investment corporation), the general manager of the carbon finance department of an established state-controlled investment corporation, the director of the carbon trading department of a major environment exchange in China, and the dead of the corporate banking department of a leading national commercial bank in China. We summarize their comments and concerns about carbon finance and emission trading in China.

\section{Domestic carbon finance}

Commercial financial services are a critical element of a functioning and efficient carbon market. Private investment is the main source of climate mitigation finance globally (ref. 5). In China, 
however, financial institutions have played a rather passive role in advancing environmental interests (ref. 6). According to the Chinese Academy of Social Sciences, China's investment in GHG mitigation has been dominated by public funds, whereas private funds are not the main source of climate finance (ref. 7). A number of structural problems contribute to the slow progress in directing private capital to the carbon market. Firstly, the regulatory and policy systems are not conducive to the deployment of climate finance. Regulatory standards and official data on emissions are far from complete and consistent, and this creates difficulties for financial institutions to assess the economic and environmental viability or risk of applications. Flaws in the legal system continue to exist and non-compliance is widespread. This raises the risk of financial frauds and gives little protection to investors in the event of financial breakdowns.

Second, financial institutions lack incentives for participation. Domestic financiers are not strongly motivated to finance emission mitigation as they do not see climate change as a profitable investment option. Although state-owned banks consider climate related investment as a corporate social responsibility issue, they are yet to include climate impacts as key considerations of business development (ref. 7). Institutional investors are not very optimistic about the prospects of financial products linked to climate change. Some commercial banks have recently set up rudimentary carbon asset management services and funds, but most hesitate to get involved and the small ones do not possess adequate knowledge and expertise in climate finance. Progress in developing new financial products, such as climate debentures and climate insurance, is slow.

\section{Emission trading market}

Carbon markets should provide favourable conditions and incentives for financial institutions to offer financial services and produce new products. Yet there is a feeling among the industry representatives that the Chinese authorities are reluctant to open up the market to financial institutions, due to risk control considerations. The larger institutional environment is deemed to be not adequately supportive.

Local governments are primarily responsible for designing and implementing the pilot ETSs. The problem is that not many government officials have adequate knowledge and relevant expertise in managing trading activities and the market generally. Financiers possess the expertise required to offer advice, but few of them have been brought into the decision-making process that determines how the ETSs will be set up and operated. It is not clear that financial institutions have made significant contributions to institutional development. Comparing the Western carbon markets, the level of finance involvement is relatively low in China.

Some of the impediments are related to the top-down approach by which the ETSs are set up. In Europe, pro-trading business coalitions played a decisive role in in the establishment of 
the EU ETS. In contrast, the Chinese carbon market is primarily established and managed by administrative means, rather than being driven by businesses' voluntary commitments to GHG mitigation (ref. 8). Most of the firms affected by the ETSs are large state-owned entreprises; they are generally willing to reduce their polluting operations to lower costs of production and cooperate with regulators (ref. 4). Although the new policies and regulations have created some market demand for emission allowances and credits, these entreprises concentrate on complying with regulatory requirements and have poor sense of comprehensive corporate carbon management and low interest in trading emission credits as a form of financial investment. As a result, corporate demand for advanced financial services linked to emission trading is weak. Many financial institutions, notably banks, lack motivation to engage with the domestic carbon markets.

In addition, current policies unnecessarily reduce profitable investment opportunities. For example, futures markets account for a much larger share of global carbon trades than spot markets do. The former involve the trading of futures contracts, which allow delivery of a commodity (e.g. carbon credits) at a specified price and time in the future, whereas the later involve immediate delivery at a given price. However, currently only spot markets are allowed to operate in China. The spot markets are financially less attractive to financial service providers and investors, because they do not allow them to speculate on prices going up or down in the future and increase profit margins by speculation and risk-taking. This significantly reduces incentives for making financial investment in the carbon markets (ref. 9). From a financial point of view, therefore, the limited trading opportunities are the main problem, rather than the lack of expertise on the part of financial institutions themselves. As one of our interviewees put it "The problem is not actually with financial institutions, but the scale of the market being not big enough, or too small to attract financial institutions”.

\section{Concluding remarks}

Low liquidity is currently the main weakness of the Chinese carbon market. The market scale has been compromised by weak corporate demand and excessive regulatory constraints. The variety of trading options and the number of trading partners are limited. Consequently, the Chinese carbon market remains narrowly defined and small, relative to other businesses and trading opportunities, and is still in a pilot phase and subject to future policy change. Expectations of low rates of return and policy uncertainties have reduced the motivation of investors and financial service providers to participate in emission trading.

A robust financial system is essential for a carbon market to thrive. Low-carbon projects and technologies are capital-intensive and typically have long payback periods. Both initial costs and investment risks are high. The government is in a position to provide short-term solutions to the shortage of domestic finance for GHG mitigation. In the past few years, the Chinese 
government has made massive investments in developing renewable energy sources and improving energy efficiency (ref. 7). To leverage these successful official efforts, more private capital should be identified and mobilized, and eventually given a central role in financing GHG mitigation. For example, banks need support from government, in the form of subsidies or tax benefits, to low their risks in providing low-carbon finance to firms. Carbon emission disclosure systems should be established to help investors and banks assess the risks of investment in lowcarbon projects. Professional training is needed for corporate environmental managers and technical bureaucrats to build capacity in emission control, monitoring as well as trading emission credits. The carbon market should be made open to a variety of trading options, such as futures contracts, to promote financial product innovation and attract capital.

Yu Xiang is at the Institute of Urban and Environmental Studies, Chinese Academy of Social Sciences, Beijing, China.e-mail: sophie.yu.xiang@gmail.com

Alex Y. Lo is at the Griffith School of Environment, Griffith University, Gold Coast, QLD 4222, Australia.e-mail: alex.lo@griffith.edu.au

\section{References:}

1. State and Trends of Carbon Pricing 2014 (World Bank, Washington, D.C., 2014).

2. Zhang, D., Karplus, V.J., Cassisa, C., Zhang, X. Energy Policy (forthcoming). http://dx.doi.org/10.1016/j.enpol.2014.01.022.

3. Han, G., Olsson, M., Hallding, K. \& Lunsford, D. China's Carbon Emission Trading: An Overview of Current Development (Stockholm Environment Institute, Stockholm, 2012)

4. Shen, W. Climate Policy (forthcoming). http://dx.doi.org/10.1080/14693062.2014.926263

5. Grubb, M., Laing, T., Counsell, T., Willan, C. Climatic Change 104, 539-573 (2011).

6. Lo, A.Y., Howes, M. Eurasian Geography and Economics 54, 386-408 (2013).

7. Pan, J., Chen, H.B., Yu, X., Wang, L.C., 2012. The demand of low-carbon finance and policy analysis, in: Wang, W., Zheng, G. (Eds.), Green Book of Climate Change: Annual Report on Actions to Address Climate Change (Social Sciences Academic Press, Beijing, 2012) pp. 2744 (in Chinese).

8. Lo, A.Y. Ecological Economics 87, 72-74 (2013).

9. Adams, M. Trials and tribulations: China experiments with carbon trading (The Economist Intelligence Unit, Hong Kong, 2013). 